\title{
Trophy aktív páncélvédelmi rendszert kapnak az M1 Abrams és a Leopard 2 típusú harckocsik
}

A 2003-as iraki invázió során, az iraki speciális erők harcosainak orosz gyártmányú 9M133 Kornet páncéltörő rakétával sikerült először kilőni az USA hadseregének meghatározó harckocsitípusát, egy M1 Abrams-t. Az iraki inváziót követő szíriai és iraki háború, valamint a jemeni konfliktus súlyos Abrams-veszteségei, továbbá az Európában egyre komolyabban vett orosz fenyegetés kikényszerítette az 1980-as években szolgálatba állított, de folyamatosan modernizált - napjainkban a legkorszerübb harckocsik közé tartozó - Abramsek aktív páncélvédelmi rendszerrel történő felszerelését.

Bár a páncélvédelmet fokozó fejlesztések, a kiegészítő páncélzat, a rétegelt, a reaktív és a robbanó reaktív páncélok jelentős mértékben növelik a harckocsik és a legénység túlélőképességét a kumulatív energiával romboló lövedé-

1. ábra. 2003 májusában az Iraki Szabadság Hadmúvelet (Operation Iraqi Freedom) során orosz gyártmányú 9M133 Kornet páncéltörő rakétával megsemmisített amerikai M1A1 Abrams harckocsi

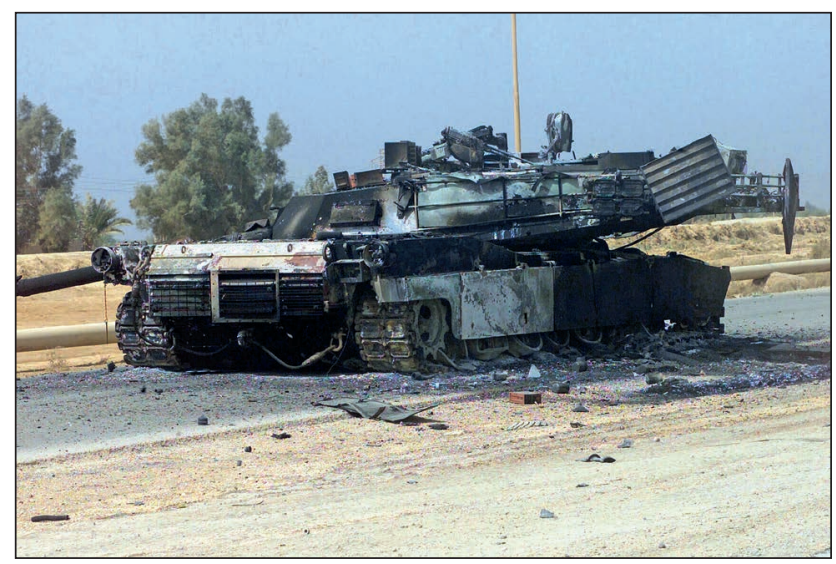

ÖSSZEFOGLALÁS: Az izraeli Rafael Advanced Defense Systems és az Elta Systems által közösen fejlesztett Trophy Active Protection System aktív páncélvédelmi rendszert kap az amerikai hadsereg négy M1A2 Abrams harckocsidandára, valamint a német Bundeswehr egyik Leopard 2A7 harckocsiszázada.

KULCSSZAVAK: USA szárazföldi erői és tengerészgyalogsága, M1 Abrams, General Dynamics Land Systems, Rafael Advanced Defense Systems, Leonardo DRS, Trophy, Iron Fist és ADS Active Protection System aktív páncélvédelmi rendszer, Leopard 2A7, Krauss-Maffei Wegmann, Rheinmetall

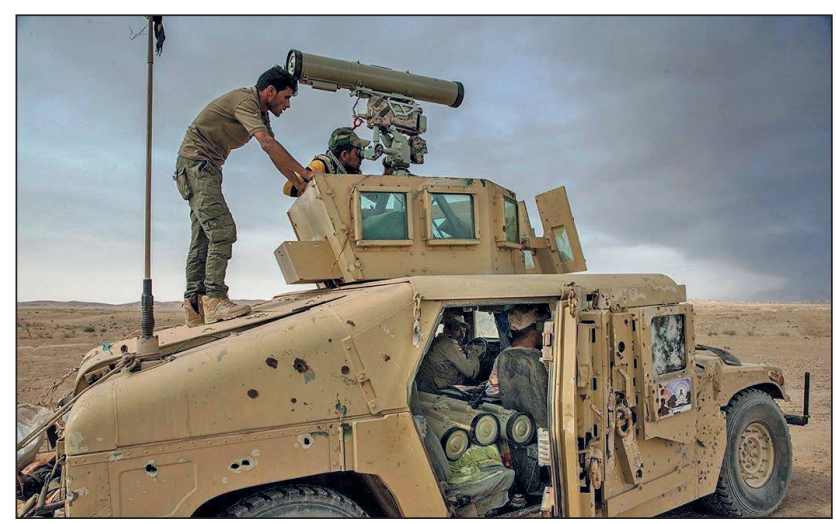

2. ábra. Egy dél-jemeni Hummer alvázára szerelt hordozható Kornet-E páncéltörőrakéta-indító

kek ellen, azonban nem nyújtanak tökéletes védelmet. Oroszország, Kína és Irán sikeresen fejlesztett olyan jármüre telepíthető vagy akár hordozható, jelentős páncélátütőképességgel rendelkező fegyvereket, mint a 9M133 Kornet, a Hongjian-8 és a Toophan irányított páncéltörő rakéta, vagy az RPG-29 és RPG-30 tandem harcifejes rakétahajtású gránátvető. (A tandem robbanófejek az ERA Explosive Reactive Armor robbanó reaktív páncélzat ellen is hatásosak.) Könnyen hozzáférhetők, olcsók és egyszerűen használhatók. Tömegesen elterjedtek az iraki, szíriai, líbiai, libanoni, gázai, valamint az afrikai és ázsiai háborús övezetekben, komoly veszélyt jelentve az amerikai páncélozott harcjárművekre.

Az izraeli Trophy Active Protection System (aktív páncélvédelmi rendszer) beszerzéséről szóló hírek 2017-ben jelentek meg először az amerikai médiában. (Izrael úttörő szerepet játszik az aktív védelmi rendszerek fejlesztésében, számos izraeli cég - IAI, IMI, Rafael - gyárt és értéke-

ABSTRACT: Four M1A2 Abrams battle tank brigades of the US Army and also one of the Leopard 2A7 battle tank company of the German Bundeswehr will receive the Trophy active protection system co-developed by Israeli Rafael Advanced Defense Systems and Elta Systems.

KEY WORDS: the Army and the Marine Corps of the US, M1 Abrams, General Dynamics Land Systems, Rafael Advanced Defense Systems, Leonardo DRS, Trophy, Iron Fist and APS Active Protection System, Leopard 2A7, KraussMaffei Wegmann, Rheinmetall

\footnotetext{
Nyá. mérnök alezredes. ORCID: 0000-0002-3732-4573
} 
sít ilyen eszközöket.) Az Egyesült Államok hadseregének vezérkari főnöke 2018 májusában jelentette a kongreszszusnak, hogy két éven belül négy M1A2-es Abrams harckocsidandárt izraeli gyártmányú, ún. „hard kill” aktív védelmi rendszerrel szerelnek fel. Ennek apropóján 2018 júniusában a US Army's Program Executive Office for Ground Combat Systems (az amerikai hadsereg szárazföldi harci rendszerek programvégrehajtó hivatala), 193 millió dollár értékű szerződést ítélt oda a Leonardo DRS (Diagnostic Retrieval Systems) szárazföldi védelmi rendszerekre szakosodott amerikai vállalatnak és izraeli partnercégének, a Trophy védelmi rendszert kifejlesztő, gyártó és forgalmazó Rafael Advanced Defense Systemsnek, csúcstechnológiájú Trophy rendszerek szálítására. A Trophy az egyetlen sorozatban gyártott, harcban tesztelt, $360^{\circ}$-os lefedettséget biztosító, 300-350 ms reakcióidejü aktív védelmi rendszer a világon. Az eszköz 2009 óta a Merkava Mk3 és Mk4 izraeli harckocsik széria-felszerelését képezi. (Az oroszok is teszteltek aktív védelmi rendszereket T-80-as és T-90es harckocsikon Csecsenföldön, Grúziában sőt Szíriában is.) A Rafael ez ideig mintegy $1500 \mathrm{db}$ Trophyt gyártott az izraeli védelmi erők részére ezekből a rendszerekből.

A Trophy kis hatótávolságú Elta EL/M-2133 F/G sávú aktív radarból, négy fázisvezérelt síkantennából, fedélzeti számítógépből és a torony két oldalára szerelt egy-egy védőtöltet-kivető egységből áll. Működési mechanizmusát a 3. ábra fázisgrafikái szemléltetik.

A radar detektálja, azonosítja és követi a közeledő fenyegetést. A fedélzeti számítógép kiszámítja az elfogási paramétereket, a védőtöltet kivetési szögét és idejét, és élesíti a védelmi mechanizmust. Amennyiben a rendszer a lövedéket valós veszélyként érzékeli, kilő egy repesztöltetet a fenyegetés irányába, hogy annak robbanásakor keletkező „repeszkúpba” berepülő lövedék robbanófejét elműködtesse, roncsolja vagy eltérítse, mielőtt az becsapódna. A radarok képernyője jelzi a fenyegetés indítási helyét is, lehetővé téve a személyzet számára az azonnali ellentevékenységet. A gyártó szerint a modernizált Trophy változat

3. ábra. A Trophy aktív védelmi rendszer múködési mechanizmusa

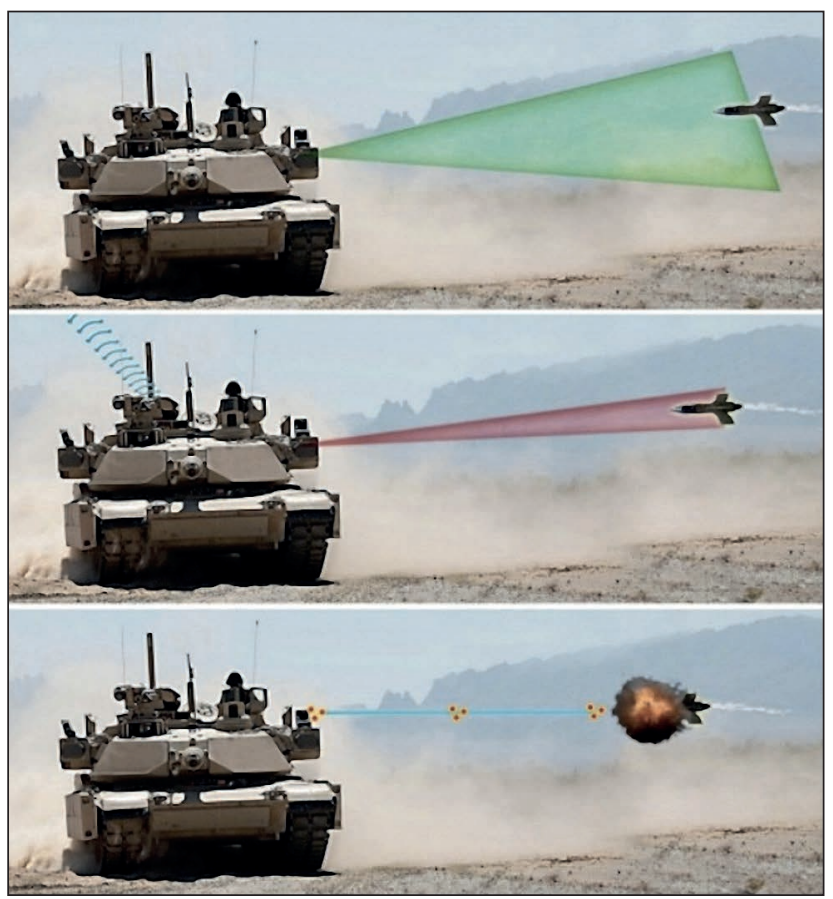

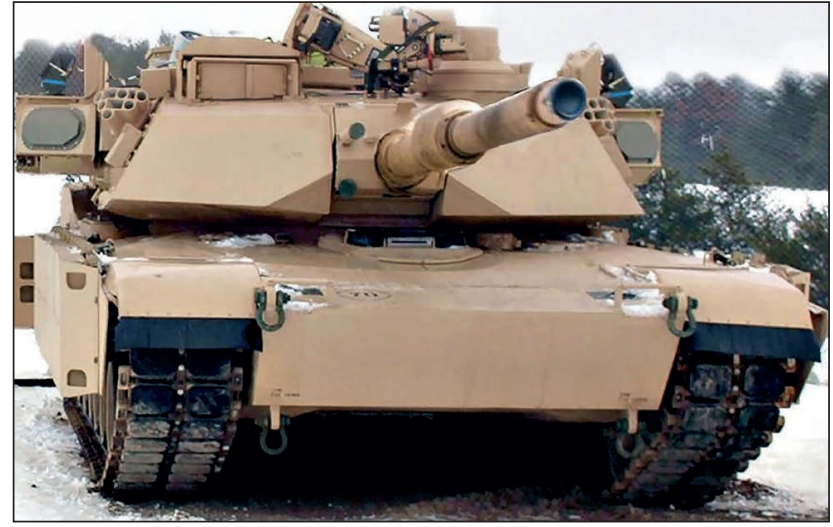

4. ábra. Trophy aktív védelmi rendszerrel felszerelt M1A2 Abrams változat. A harckocsitorony bal és jobb oldalán jól látható egy-egy nyolcszögletü, repeszvédett radarantenna, mögötte egy-egy repesztöltet-kivető egység

egyszerre 17 védőtöltet indítására is alkalmas páncéltörő rakéták ellen. A rendszer hátránya, hogy a védőtöltetek robbanása során keletkező repeszek a harckocsit kísérő gyalogság számára sérüléseket okozhatnak.

2019-ben a Pentagon 261 db csúcstechnológiájú Trophy rendszer beszerzését finanszírozta. (A becsült beszerzési ár 350000 dollár/harckocsi.) A szállítást a Leonardo DRS, a telepítést az M1 Abramsek gyártója, a General Dynamics Land Systems végzi a Missouri állambeli St. Louis-ban. A Trophy alkatrészeit részben az amerikai, részben az izraeli védelmi ipar gyártja. A projekt végrehajtásának tervezett határideje: 2020. március 31.

2019 októberében a Leonardo DRS és a Rafael jelentette, hogy a szerződés szerinti - az amerikai haderő operatív igényeihez hozzáigazított - első tétel Trophy leszállítását megkezdték. Első ütemben az a két M1A2-es dandár kapja meg a Trophyt, amelyeket az Operation Atlantic Resolve („Atlanti megoldás” hadművelet) keretében, 2020-ban áttelepítettek Európába. (Ez a művelet Oroszország 2014-es ukrajnai beavatkozásával, a Krím térségének annektálásával vette kezdetét.)

A szállításról szóló bejelentést többéves kvalifikációs eljárás, tesztek és éleslövészetek előzték meg. Az Egyesült Államok és Izrael kormányának és iparának szakértői közösen dolgoztak azon, hogy egy kritikus képességhiányt megszüntetendő, a Trophyt a szárazföldi erők és a tengerészgyalogosok M1A1/A2 Abrams harckocsijaiba telepítsék.

Az amerikai és izraeli szakértők további két aktív páncélvédelmi rendszert is vizsgáltak: az Israel Military Industries Iron Fist (,vasököl”) rendszerét az M2 Bradley gyalogsági harcjárműveken, és az amerikai Artis cég Iron Curtain (,vasfüggöny”) rendszerét a Stryker páncélozott harcjárműveken. A tesztelésen amerikai részről az Operational Test Command, továbbá a Fort Hood (Texas), az Aberdeen Test Center és az Aberdeen Proving Ground (Maryland), a Yuma Test Center és a Yuma Proving Ground (Arizona), valamint a Redstone Test Center (Alabama) szakértői vettek részt. A 27 t-s Bradley lánctalpas harcjármübe a Trophy helyett a konkurens Israel Military Industries hasonló rendszerű, de a Trophynál kisebb tömegű, kompaktabb és olcsóbb Iron Fist aktív védelmi rendszerét építették be. Ez a moduláris felépítésű konstrukció szintén minimális repeszképzéssel semmisíti meg vagy tereli el a páncéltörő rakétát, csökkentve a közvetett károkat vagy a jármű közelében lévő katonák sérüléseit. (A Trophy mellett az izraeli hadsereg is használja az Iron Fistet a Namer páncélozott gyalog- 
1. táblázat. M1A2 Abrams harckocsi főbb müszaki paraméterei

\begin{tabular}{|l|c|}
\hline \multicolumn{2}{|c|}{ Általános tulajdonságok } \\
\hline Tömeg & $69,54 \mathrm{t}$ \\
\hline $\begin{array}{l}\text { Hosszúság (elöremutató } \\
\text { lövegcsővel) }\end{array}$ & $9,77 \mathrm{~m}$ \\
\hline Páncéltest hosszúsága & $7,93 \mathrm{~m}$ \\
\hline Magasság & $2,44 \mathrm{~m}$ \\
\hline Szélesség & $3,66 \mathrm{~m}$ \\
\hline \multicolumn{2}{|c|}{ Páncélzat és fegyverzet } \\
\hline
\end{tabular}

\begin{tabular}{|l|c|}
\hline \multicolumn{2}{|c|}{ Páncélzat és fegyverzet } \\
\hline Páncélzat & $\begin{array}{c}\text { Chobham kompozit } \\
\text { páncél. (A homlok-páncél } \\
\text { és a torony gyengített } \\
\text { uránnal megerősített) }\end{array}$ \\
\hline Fő fegyverzet & $\begin{array}{c}\text { M256A1 } 120 \mathrm{~mm} \text {-es sima } \\
\text { csövű ágyú, a Rhreinmetall } \\
\text { licencben gyártott } \\
\text { változata }\end{array}$ \\
\hline
\end{tabular}

2,7 mm-es Browning M2

HB (Heavy Barrel) típusú nehéz géppuska;

Másodlagos fegyverzet

7,62 mm-es M240

párhuzamosított géppuska;

7,62 mm-es M240

légvédelmi géppuska

\begin{tabular}{|c|c|}
\hline \multicolumn{2}{|c|}{ Lőszer-javadalmazás } \\
\hline 120 mm-es lőszer & $40 \mathrm{db}$ \\
\hline 12,7 mm-es lőszer & $1000 \mathrm{db}$ \\
\hline 7,62 mm-es lőszer & $12400 \mathrm{db}$ \\
\hline \multicolumn{2}{|c|}{ Múszaki adatok } \\
\hline Erőforrás & $\begin{array}{c}\text { Honeywell AGT-1500 } \\
\text { vegyes üzemű gázturbina }\end{array}$ \\
\hline Erőforrás-teljesítmény & 1103 kW (1500 LE) \\
\hline Teljesítmény/tömegarány & $21,6 \mathrm{LE} / \mathrm{t}$ \\
\hline Sebesség & $\begin{array}{c}\text { A gázturbina } 67 \mathrm{~km} / \mathrm{h} \\
\text { előremeneti és } 42 \mathrm{~km} / \mathrm{h} \\
\text { hátrameneti sebességre } \\
\text { képes felgyorsítani a } \\
\text { harckocsit }\end{array}$ \\
\hline Hatótávolság & $426 \mathrm{~km}$ \\
\hline \multicolumn{2}{|c|}{ Erőátvitel } \\
\hline Nyomatékváltó & $\begin{array}{c}\text { Négy előre- és két } \\
\text { hátrameneti fokozatú } \\
\text { Allison DDA X-1100-3B } \\
\text { váltómü }\end{array}$ \\
\hline
\end{tabular}

sági harcjárműveken.) A Stryker kerekes harcjárműre szerelt Iron Curtain azonban esőben és hóesésben nem müködött megbízhatóan, és egyenetlen terepen történő mozgás közben sem hozta az elvárt hatékonyságot. Így a járművön már kipróbált Trophy Light, Iron Fist és a Rheinmetall Defence ADS (Active Defence System) rendszer után a 19 t-s Stryker továbbra is egy olyan megbízható aktív védelmi rendszerre vár, amely a kisebb, könnyebb páncélozott járművekhez is használható.
Médiahírek szerint a közel 200 millió dolláros Trophybeszerzés célja akár az is lehet, hogy az amerikai MAPS (Modular Active Protection Systems) - moduláris aktív védelmi program megvalósulásáig biztosítsa az amerikai harcjárművek átmeneti bevethetőségét. Az amerikai vezetés ugyanis perspektivikusan egy soft kill-hard kill elemeket kombináló, nyílt architektúráiú, moduláris aktív védelmi projektet kíván megvalósítani, amely moduláris kialakításának köszönhetően különféle védelmi rendszerekből számos ellenintézkedés-típust képes hasznosítani. A Lockheed Martin még 2014-ben nyerte el a megbízást, hogy egyetlen moduláris rendszerbe integrálja három gyártó, az Ariel Photonics, a BAE Systems és a Northrop Grumman védelmi rendszerét, valamint egy szenzorcsoportot. 2019 márciusában a MAPS-rendszer - fejlesztése első fázisának befejeztével - hathetes tesztsorozat keretében vizsgázott, ennek során az irányított páncéltörő lövedékekből valamennyit sikerült hatástalanítania. (A MAPS egyelőre csak az irányított páncéltörő rakéták hatástalanítására képes.)

A Bundeswehrben 1979-ben rendszeresített és a legkorszerűbb harckocsik közé tartozó Leopard 2-es harckocsit gyakran hasonlítják az M1 Abramshez. Mindkét konstrukció hasonló paraméterekkel bír, beleértve a 70 t közeli össztömeget, a 1103 kW (1500 LE) teljesítményű motort, és a sima csövű 120 mm-es harckocsiágyút. A KrausMaffei Weigman $\mathrm{GmbH}$ \& CO KG (ma már KMW+Nexter Defense Systems) fejlesztésű német Leopardokat a szakma évtizedekig elpusztíthatatlannak tartotta. Sebezhetetlenségi mítoszuk 2016 decemberében a szíriai Al-Bab város körüli harcokban ért véget, amikor a korábban csak aszimmetrikus konfliktusokban vagy békemissziókban alkalmazott, városharcra felkészítetlen, kiegészítő védelemmel (reaktív páncélzattal vagy aktív páncélvédelmi rendszerrel) nem rendelkező török Leopard 2A4-eseket az Iszlám Állam (IS) harcosai páncéltörő rakétákkal kilőttek. A páncéltörőrakéta-találatok túlnyomórészt a harckocsilövegtornyok vékonyabb páncélzatú oldalát vagy hátulsó részét érték. DPA (Deutsche Presse-Agentur) információk szerint a török Leopardok közül legalább tíz megsemmisült vagy súlyosan megsérült. A tíz harckocsiból legalább hatot az 1,2 m vastagságú páncél átütésére képes, 9M133 Kor-

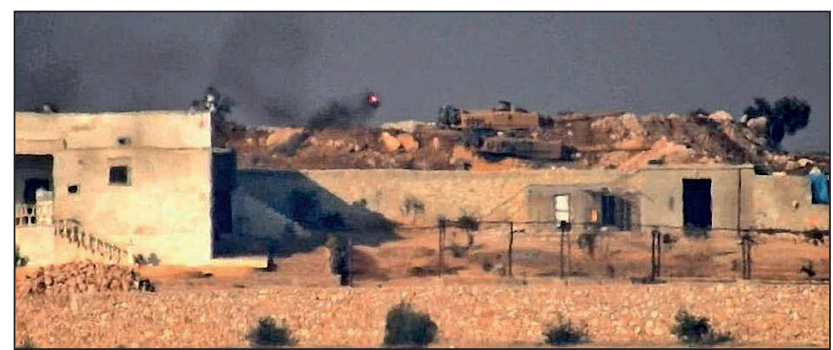

5. ábra. Így közelítette meg a páncéltörő rakéta (piros pont) a képen látható két török Leopard 2A4 egyikét

\section{6. ábra. A rakétabecsapódást követő robbanás pillanata}

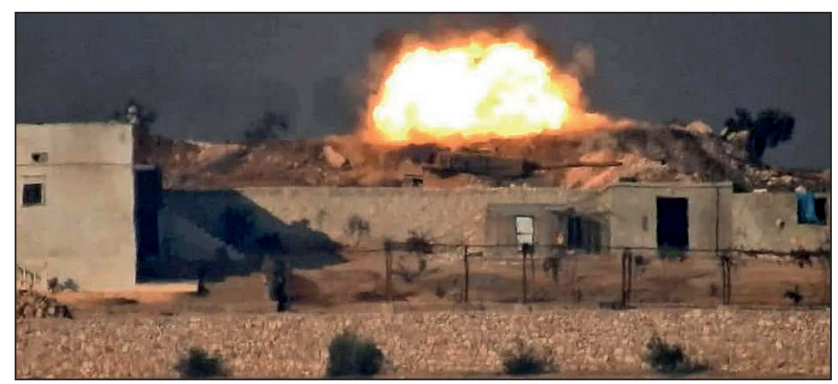


net rakétával pusztítottak el. (Valójában évtizedek óta folyik a verseny a harckocsi- és a páncéltörőfegyver-gyártók között, hogyan védjék, vagy pusztítsák a páncélosokat. Rendhagyó módon, a piacvezető harckocsigyártók páncéltörő lőszereket is fejlesztenek.)

A Leopard 2A4 meglévő képességhiányát megszüntetendő, a török vezetés 2018 márciusában bejelentkezett a Rheinmetall Groupnál, mintegy 100 db ADS aktív védelmi rendszer beszerzése érdekében. A csaknem kész szerződésről - a Törökországba irányuló fegyverkivitel ideiglenes tilalma miatt - már csak a német kormány jóváhagyása hiányzik.

Bundeswehr döntéshozói 2019 januárjában megerősítették, hogy a NATO VJTF (Very High Readiness Joint Task Force) nagyon magas készenlétű erőkhöz 2023-ban csatlakozó Leopard 2A7 harckocsiszázadot a Rafael Trophy aktív védelmi rendszerével fogják felszerelni. (A NATO állam- és kormányfői a VJTF létrehozásáról a 2014. szeptemberi walesi csúcstalálkozón állapodtak meg, válaszul a megváltozott európai biztonsági környezetre, beleértve Oroszország agresszív fellépését Ukrajna ellen.) A BAAINBw (Bundesamt für Ausrüstung, Informationstechnik und Nutzung der Bundeswehr), a Bundeswehr beszerzési hivatala az első prototípusra vonatkozó szerződést a Rafaellel még 2019-ben megkötötte.

Noha a részletek még hiányosak, a Kraus-Maffei Wegmann $\mathrm{GmbH}$ \& Co. KG, mint a Leopard 2-es harckocsik fejlesztője és gyártója, (2019-ben ünnepelte világhírű modellje 40 éves jubileumát) bejelentette, hogy a Rafaellel együttműködésben megkezdte a Trophy-rendszer tesztelését a Leopard 2A7-esen. A tesztelés befejezését 2021-re tervezik. A 17 harckocsiból (13 bevetési és 4 tartalékból) álló század a Trophyt előreláthatólag 2022-ben kapja meg, és a kiképzés utáni készenlétet elérve, várhatóhatóan 2023-ban csatlakozhat a NATO gyorsreagálású erőkhöz. A Bundeswehr egyébként bőséges Trophy és Iron Fist rendszerekkel kapcsolatos tapasztalattal rendelkezik, mivel évekkel ezelőtt mindkét eszköz alkalmazhatóságát már vizsgálta a Leopard 2A6, 2A6M és $2 \mathrm{~A} 7$ változatokon.

Németország részéről az izraeli Rafael által gyártott technológia kiválasztása valószínűleg a korábbi amerikai döntés nyomán született, a Kraus-Maffei Wegmannal konkurens Rheinmetall moduláris felépítésű, és a Trophynál rövidebb reakcióidejű (500 $\mu \mathrm{s})$, hard kill típusú ADS védelmi rendszerével szemben. (A Rheinmetall 74\%-os részvénytöbbségű leányvállalata, az ADS GmbH által kifejlesztett, csökkent energiaigényű rendszer szinte minden járműtípusra adaptálható. A prototípusokat már több harcjármüvön - többek között a német Marder, a svéd SEP és CV90,

\section{7. ábra. Trophy aktív védelmi rendszerrel felszerelt Leopard} 2A7 harckocsi látványképe. A harckocsitorony elülső részén jól látható a nyolcszögletű, repesz ellen védett radarantenna

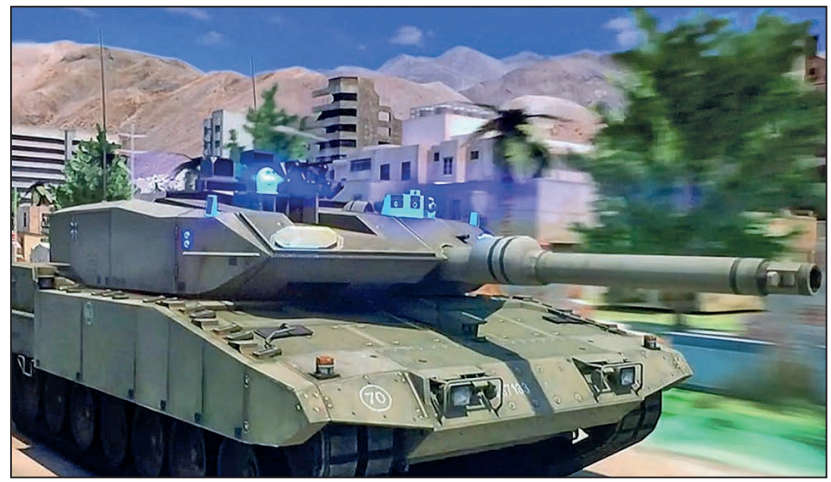

2. táblázat. Leopard $2 A 7$ harckocsi föbb müszaki paraméterei

\begin{tabular}{|c|c|}
\hline Tömeg & $67,5 \mathrm{t}$ \\
\hline $\begin{array}{l}\text { Hosszúság (előremutató } \\
\text { lövegcsővel) }\end{array}$ & $10,97 \mathrm{~m}$ \\
\hline Páncéltest hossza & $7,7 \mathrm{~m}$ \\
\hline Magasság & $2,64 \mathrm{~m}$ \\
\hline Szélesség & $4 \mathrm{~m}$ \\
\hline \multicolumn{2}{|c|}{ Páncélzat és fegyverzet } \\
\hline Páncélzat & $\begin{array}{l}\text { Harmadik generációs, } \\
\text { négyrétegű Chobham } \\
\text { kompozit páncél }\end{array}$ \\
\hline Fő fegyverzet & $\begin{array}{c}\text { Rheinmetall } 120 \text { mm } \\
\text { ürméretű sima csövű } \\
\text { harckocsiágyú }\end{array}$ \\
\hline Másodlagos fegyverzet & $\begin{array}{c}\text { 7,62 mm-es MG2 } \\
\text { párhuzamosított géppuska, } \\
\text { 7,62 mm-es MG3 } \\
\text { légvédelmi géppuska, } \\
76 \text { mm-es, egyenként } \\
\text { nyolccsövü ködgránátvető } \\
\text { a torony két oldalán }\end{array}$ \\
\hline \multicolumn{2}{|c|}{ Lőszer-javadalmazás } \\
\hline 120 mm-es lőszer & $42 \mathrm{db}$ \\
\hline $\begin{array}{l}\text { 7,62 mm-es } \\
\text { géppuskalőszer }\end{array}$ & $4200 \mathrm{db}$ \\
\hline \multicolumn{2}{|c|}{ Múszaki adatok } \\
\hline Erőforrás & $\begin{array}{c}\text { MTU MB } 873 \text { Ka-501 V12 } \\
\text { hengeres turbófeltöltős } \\
\text { dízelmotor }\end{array}$ \\
\hline Erőforrás-teljesítmény & 1103 kW (1500 LE) \\
\hline Teljesítmény/tömeg arány & 22,3 LE/t \\
\hline Sebesség & $\begin{array}{l}\text { A dízelmotor } 72 \mathrm{~km} / \mathrm{h} \\
\text { sebességre képes } \\
\text { felgyorsítani a harckocsit, } \\
\text { hátramenetben } 32 \mathrm{~km} / \mathrm{h} \text { a } \\
\text { maximális sebessége }\end{array}$ \\
\hline Hatótávolság & $450 \mathrm{~km}$ \\
\hline \multicolumn{2}{|c|}{ Erőátvitel } \\
\hline Nyomatékváltómű & $\begin{array}{c}\text { Renk HSVL } 354 \\
\text { hidromechanikus váltó, } \\
\text { négy előre- és két } \\
\text { hátrameneti fokozattal }\end{array}$ \\
\hline
\end{tabular}

a francia VAB, az olasz Iveco LMV, a kanadai LAV III és az amerikai Stryker járműveken, sőt a Leopard 2A7-es harckocsin is - sikeresen tesztelték. Svédországban AAC, Franciaországban Shark néven ismert. A NATO-régió és Ázsia fegyveres erői nagy érdeklődést tanúsítanak az ADS technológiája iránt.)

A Trophy-beszerzés pillanatnyilag csak a tervezett 17 rendszerre korlátozódik, a Bundeswehr hosszú távon nem kötelezte el magát nagyobb volumenű beszerzésre.

Említésre érdemes esemény a TASZSZ orosz hírügynökség 2019. júniusi, izraeli forrásra hivatkozó azon jelentése, hogy a páncéltörő rakéták megsemmisítésére kifejlesztett 


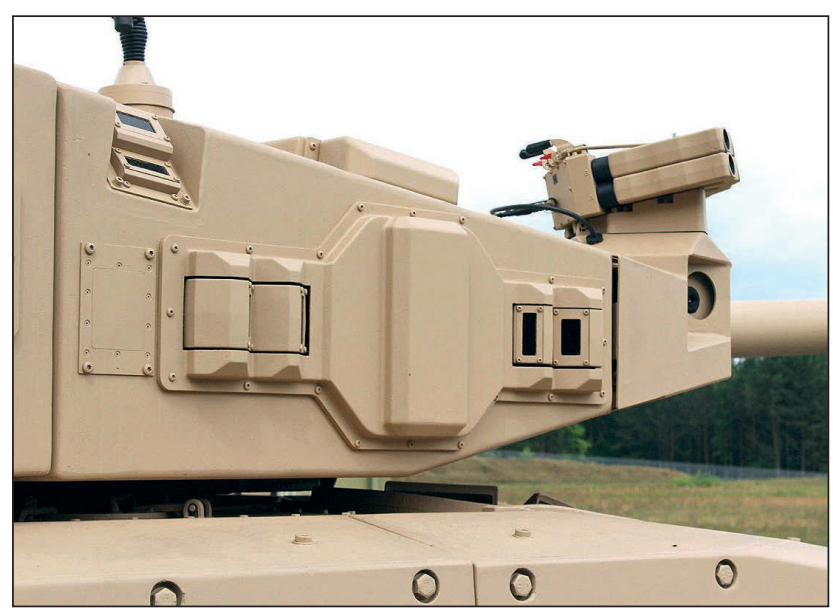

8. ábra. A Rheinmetall cég Leopard $2 A 7$ toronyra szerelt 500 us reakcióidejú, elektro-optikai érzékelős AMAP-ADS aktiv védelmi rendszere

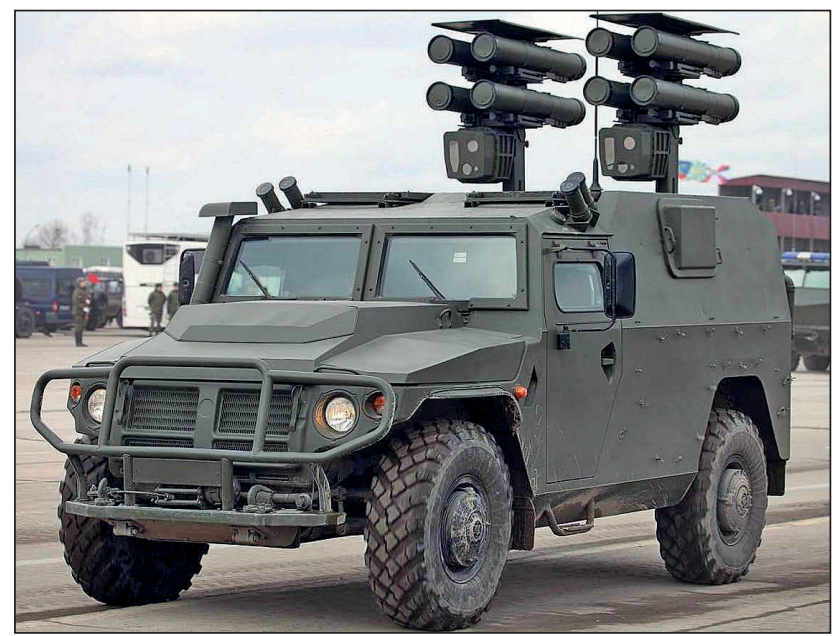

9. ábra. Oroszország egyik legújabb 9M133M Kornet-M „önjáró” páncéltörörakéta-indító rendszere

izraeli Trophy aktív védelmi rendszer nem nyújt 100\%-os védelmet az orosz páncéltörő fegyverek ellen, nem minden esetben képes detektálni és megsemmisíteni az egymás után $0,2-0,4$ s időintervallumonként indított két vagy három páncéltörő lövedéket. Ilyen technológiát alkalmaznak ugyanis a korszerűsített Kornet páncéltörő rakétáknál és az egyszer használatos gránátvetőknél. A Trophy fázisvezérelt radart használ az érkező lövedékek detektálására, hogy megsemmisítse azokat a röppályájukra kivetett repesztöltettel. Kérdés, hogy egymás után beérkező több lövedék a Trophy működését ellehetetleníti-e? A 9M133 Kornet-EM indítójárműve képes két rakétát minimális időközönként indítani, míg az RPG-30 páncéltörő rakéta a nagykapacitású harci gránát mellett egy csali rakétával is fel van szerelve, amelyet közvetlenül a harci gránát indítása előtt lőnek ki - írta a TASZSZ. A Trophy bírálatával Oroszország lényegében az Egyesült Államok azon stratégiáját bírálja, hogy megvédi drága páncélozott járműveit a páncéltörő fegyverekkel szemben. Miközben Oroszország a nyugatot arra ösztönzi, hogy az aktív védelmi rendszereket elvesse, Afganit nevű aktív védelmi rendszert épít az új T-14 Armata harckocsijaiba.

A cikk hazai vonatkozása, hogy a Magyar Honvédség szárazföldi haderőnemét megerősítendő, a Zrínyi 2026 honvédelmi és haderőfejlesztési program keretében a kö- zelmúltban 44 db új Leopard 2A7+ harckocsi beszerzéséről született döntés. A beszerzéssel a magyar haderő harci képességei is javulnak. A hagyományos, városi és aszimmetrikus hadviselésre egyaránt alkalmas $2 \mathrm{~A} 7+$ változat megerősített passzív védelemmel, hagyományos és RPG rakéták elleni rácspáncélzattal rendelkezik.

\section{FoRRÁsOK}

Spencer. „Trophy active protection systems schützt nun die US M1 Abrams panzer" Spartanat, 2019.10.21. Letöltve: 2020.01.09. https://www.spartanat. com/2019/10/trophy-active-protection-systemsschuetzt-nun-die-us-m1-abrams-panzer/;

Heiming, Gerhard. „Serienauslieferung Trophy APS an die U.S. Army hat begonnen" Europäische Sicherheit \& Technik, 2019.10.15. Letöltve: 2020.01.09 https://esut. de/2019/10/meldungen/ruestung2/16034/

serienauslieferung-trophy-aps-an-die-u-s-army-hatbegonnen/;

„M1 Abrams Main Battle Tank (MBT).” Military Factory. Letöltve: 2020.01.09. https://www.militaryfactory.com/ armor/detail.asp?armor_id=1;

„US: 261 M1 Abrams tanks to receive Rafael's Trophy Active Protection System." Army Recognition, 2018.02.14. Letöltve: 2020.01.09. https://armyrecognition.com/february_2018_global_ defense_security_army_news_industry/us_261_m1_ abrams_tanks_to_receive_rafaels_trophy_active_ protection_system.html;

„Trophy active protection systems delivered to U.S. Army" Leonardo DRS, 2019.10.11. Letöltve 2020. 01. 09. https://www.leonardodrs.com/news/press-releases/ first-production-trophy-active-protection-systemsdelivered-to-us-army/;

Rogoway, Tyler. „Images Emerge Of M1A2 Abrams Tank Equipped With Trophy Active Protection System" Thedrive Letöltve: 2019.01.09.

https://www.thedrive.com/the-war-zone/14966/ images-emerge-of-m1a2-abrams-tank-equipped-withtrophy-active-protection-system;

M1A2 Abrams main battle tank. Military-today.com. Letöltve. 2020. 01. 09. http://www.military-today.com/tanks/m1a2_abrams.htm. „US-Top-General: M1-Abrams-Panzer ist nicht mehr die Nummer Eins" Stern, 2017.03.31. Letöltve: 2020.01.09. https://www.stern.de/digital/technik/kampfpanzer--m1abram-ist-nicht-mehr-die-nummer-eins-7394016.html;

Mizokami, Kyle. „U.S. Army Tanks to Get Active Protection Systems by 2020" Popular Mechanics, 2017.10.10. Letöltve: 2020.01.09.

https://www.popularmechanics.com/military/weapons/ news/a28576/us-army-tanks-to-get-active-protectionsystems-by-2020/;

„Israeli Rafael Trophy to protect German Leopard 2 main battle tanks" Army Recognition, 2019.01.29. Letöltve: 2020.01.09. https://www.armyrecognition.com/ january_2019_global_defense_security_army_news_ industry/israeli_rafael_trophy_to_protect_german_ leopard_2_main_battle_tanks.html;

Malyasov, Dylan. „U.S. Army tests Trophy Active Protection System for tanks" Defence Blog, 2019.01.18. Letöltve. 2020. 01. 09. https://defence-blog.com/ army/u-s-army-tests-trophy-active-protection-systemfor-tanks.html?fbclid=IwAR1Ylypy5PKX34du62-LjIGTEI EYvo1ZV1cPSLP9SWIGJEh3TW0TnDDMJ2Q; 
Barrie, Allison. „US Army tanks get futuristic shields to destroy incoming threats" Fox News, 2018 03. 01. Letöltve: 2019.01.09.

https://www.foxnews.com/tech/us-army-tanks-getfuturistic-shields-to-destroy-incoming-threats;

Minick, Benjamin. „US Army To Test Israeli Tank Protection System In Defender Europe War Games" International Businness Times, 2019.01.11. Letöltve: 2020. 01. 09. https://www.ibtimes.com/us-army-testisraeli-tank-protection-system-defender-europe-wargames-2858374;

„How Active Protection Systems Knock Down Anti-Armor Threats for Both Legacy and Future Combat Vehicles" Breaking Defence, 2019. 10. 15. Letöltve: 2020. 01. 09. https://breakingdefense.com/2019/10/how-activeprotection-systems-knock-down-anti-armor-threats-forboth-legacy-and-future-combat-vehicles/;

Barrie, Allison. „,Force field' technology could make US tanks unstoppable" Fox News, 2018. 08.02.

Letöltve: 2020. 01. 09. https://www.foxnews.com/tech/ force-field-technology-could-make-us-tanks-unstoppable;

Kowak, D. „Hardkill APS: Active Protection System” Militarypedia 2017, 12.10. Letöltve. 2020. 01. 09. https://www.militarypedia.it/hardkill-aps-activeprotection-system/;

Frank, Dorothee. „Deutsche Leoparden erhalten Trophy” Europäische Sicherheit \& Technik, 2019.01.28.

Letöltve: 2020. 01. 09.

https://esut.de/2019/01/meldungen/ruestung2/10349/ leoparden-trophy-rafael/;

Hegmann, Von Gerhard. „Jetzt kommt der Panzerschutz mit Pyrotechnik" Welt, 2017.03.16. Letöltve. 2020. 01. 09. https://www.welt.de/wirtschaft/article162865990/ Jetzt-kommt-der-Panzerschutz-mit-Pyrotechnik.html;

Wegner, Mathias. „Dieses System soll den Leopard wieder wettbewerbsfähig machen" Junge Freiheit, 2019.11.29. Letöltve: 2020. 01. 09.

https://jungefreiheit.de/debatte/kommentar/2019/ dieses-system-soll-den-leopard-wiederwettbewerbsfaehig-machen/;

Hegmann, Von Gerhard. Leopard-Panzer bekommen jetzt ein „Hard Kill“-System zur Raketenabwehr” Welt, 2019.11.21. Letöltve. 2020. 01. 09.

https://www.welt.de/wirtschaft/article203692040/

Aktiver-Schutz-Leopard-Panzer-bekommen-jetzt-einHard-Kill-System-zur-Raketenabwehr.html.

\section{John Flournoy Montgomery}

\section{Magyarország, a vonakodó csatlós}

John Flournoy Montgomery, a kötet szerzője amerikai üzletember és diplomata, aki 1933 júniusa és 1941 márciusa között az Amerikai Egyesült Államok magyarországi nagykövete volt. Magyarország, a vonakodó csatlós című könyvének első kiadása angol nyelven Hungary The Unwilling Satellite címmel 1947-ben jelent meg. Emlékiratát Magyarország II. világháborús útjának egyik koronatanújaként vetette papírra; írásában az ország politikai magartartásásnak már-már metaforikus összegzését kínálja. A könyv Frank Tibor az ELTE professzorának szerkesztésében és bevezető tanulmányával bővítve látott napvilágot.

Frank Tibor szavait idézve „John Flournoy Montgomery könyve nagyon érdekes, és egyéni képet ad Magyarország háborús útjáról, amelyet különleges helyzetből szemlélt, és bizonyos tekintetben jól is látott... Nem volt számottevő nemzetközi tapasztalata, politikai áttekintése, történelmi tudása. Mégis: megszerette hazánkat, jót akart neki, és kiállt mellette, és nemcsak szerepe volt, hanem helye is van a magyar múltban..."

A kötet érdekessége, hogy a három részből álló emlékirat mellett négy függelék is helyett kapott benne: az 1939. évi orosz-német megnemtámadási paktum titkos jegyzőkönyvének szövege, Horthy kormányzó 1944 októberi kiáltványa, a svájci követség jelentése Magyarország orosz megszállásáról 1945 tavaszán, és titkos érintkezések Sándor jugoszláv király és Mussolini között.

A visszaemlékezést követően egy-egy önálló fejezet foglalkozik az 1933 és 1945 között megkötött és felbontott, Magyarországot érintő szerződésekkel és egyezményekkel, valamint területi átalakításokkal. A kiegészítő részekben az érdeklődők megtalálják a szerző által összeállított, Magyarországgal foglalkozó művek bibliográfiáiát, a könyvben említett személyek életrajzi adatait, valamint - Frank Tibor szerkesztésében - a témával foglalkozó újabb forrásokat és szakirodalmi jegyzéket.

A könyvet elsősorban a Magyarország politikatörténete és történelme iránt érdeklődő olvasóknak ajánljuk. Az amerikai diplomata memoárkötete figyelemre méltó módon járul hozzá az országunk geopolitikai fekvéséből következő történelmi események és nemzeti tragédiák megértéséhez.

A Zrínyi Kiadó által megjelentetett, puha kötésű kötet terjedelme 335 oldal. 2500 Ft-os áron kaptaható a könyvesboltokban, illetve közvetlenül a Zrínyi Kiadótól is, 25\%-os helyszíni kedvezménnyel.

Cím: 1087 Budapest, Kerepesi út 29/b, (tel.: 06 1-459-5373, e-mail: gyoredina@armedia.hu). (W. T.) 